\title{
The Relationship between the Sydney Classification and the First-Line Treatment Efficacy in Helicobacter-Associated Gastritis
}

\author{
Elif Şenocak Taşçı ${ }^{a}$ Türkay Akbaş ${ }^{b}$ \\ ${ }^{a}$ Department of Internal Medicine, Acıbadem Mehmet Ali Aydınlar University School of Medicine, Istanbul, Turkey; \\ ${ }^{b}$ Department of Internal Medicine and Critical Care Unit, Düzce University School of Medicine, Düzce, Turkey
}

\section{Highlights of the Study}

- Severity of chronic inflammation, where bacterial density is the highest, was found as the most effective criteria for eradication.

- The presence of intestinal metaplasia (IM) and atrophy requires only an absolute treatment.

- The presence of IM is not a decisive criterion for the success of the standard triple therapy.

\section{Keywords}

Eradication · Gastritis · Helicobacter pylori ·

Intestinal metaplasia. Sydney classification

\begin{abstract}
Objective: Helicobacter pylori is responsible for a wide spectrum of diseases. Due to ease of use and access, the standard triple therapy is being used as first-line eradication in many areas. Intestinal metaplasia (IM) is a precancerous lesion that requires eradication therapy. Our aim is to investigate the effect of IM on the standard triple therapy success in $\mathrm{H}$. pylori-positive patients. Subjects and Methods: The patients who were referred to Düzce University Hospital and Avrasya Hospital Gastroenterohepatology clinic between January 2014 and December 2016 and diagnosed with H. pylori-positive gastritis and underwent first-line eradication were evaluated retrospectively. Biopsy specimens were evaluated according to the updated Sydney system. All patients diagnosed with $H$. pylori started treatment with pantoprazole 40 mg b.i.d., amoxicillin $1 \mathrm{~g}$ b.i.d. and clarithromycin $500 \mathrm{mg}$
\end{abstract}

karger@karger.com www.karger.com/mpp

Karger $\stackrel{\text { ' }}{5}$

GOPEN ACCESS
(C) 2020 The Author(s)

Published by S. Karger AG, Basel

This is an Open Access article licensed under the Creative Commons Attribution-NonCommercial-4.0 International License (CC BY-NC) (http://www.karger.com/Services/OpenAccessLicense), applicable to the online version of the article only. Usage and distribution for commercial purposes requires written permission. b.i.d. for 14 days. Results: The mean age of 181 patients included in the study was $55.5 \pm 7.8$. The success rate of $H$. pylori eradication was found to be low in severe chronic inflammation $(p=0.001)$. The success rate was found to be high among patients with no neutrophil activity $(p=0.009)$. As the intensity of IM increased, density of $H$. pylori was found to be decreased $(p=0.019)$. There was no correlation between glandular atrophy, IM, and $H$. pylori eradication success rate ( $p=0.390$ and $p=0.812$ ). Conclusion: The severity of chronic inflammation is the most effective Sydney criteria for success of eradication, while the presence on IM does not have any effect.

(c) 2020 The Author(s)

Published by S. Karger AG, Basel

\section{Introduction}

Helicobacter pylori infection, which affects $50 \%$ of the world's population, causes chronic and nonatrophic gastritis which then leads to atrophic gastritis and intestinal metaplasia (IM) [1]. Since the presence of IM and atrophy 
Table 1. The parameters and scale values used in histopathological staging of biopsy preparations according to Sydney classification

\begin{tabular}{|c|c|c|c|c|c|}
\hline \multirow[t]{2}{*}{ Feature } & \multirow[t]{2}{*}{ Definition } & \multicolumn{4}{|l|}{ Degree } \\
\hline & & 0 (none) & 1 (mild) & 2 (moderate) & 3 (severe) \\
\hline Chronic inflammation & $\begin{array}{l}\text { Density of the lymphocytes and } \\
\text { plasma cells in the lamina propria }\end{array}$ & $\begin{array}{l}2-5 \text { lymphocyte, } \\
\text { plasma and } \\
\text { macrophage }\end{array}$ & $5-10$ cells $\times 40$ & $11-20$ cells $\times 40$ & $>21$ cells $\times 40$ \\
\hline Neutrophil infiltration & $\begin{array}{l}\text { Neutrophilic infiltrates of the lamina } \\
\text { propria or surface epithelium }\end{array}$ & None & $\begin{array}{l}<1 / 3 \text { of surface } \\
\text { infiltrated }\end{array}$ & $\begin{array}{l}1 / 3-2 / 3 \text { of surface } \\
\text { infiltrated }\end{array}$ & $\begin{array}{l}>2 / 3 \text { of surface } \\
\text { infiltrated }\end{array}$ \\
\hline Glandular atrophy & Loss of specialized glands & None & Mild & Moderate & Severe \\
\hline Intestinal metaplasia & Intestinal metaplasia of the epithelium & None & $\begin{array}{l}<1 / 3 \text { of mucosa } \\
\text { involved }\end{array}$ & $\begin{array}{l}1 / 3-2 / 3 \text { of mucosa } \\
\text { involved }\end{array}$ & $\begin{array}{l}>2 / 3 \text { of mucosa } \\
\text { involved }\end{array}$ \\
\hline H. pylori & Density of $H$. pylori overlying epithelium & None & 1-3 organism & A layer of bacterium & $\begin{array}{l}\text { Cluster of } \\
\text { bacterium }\end{array}$ \\
\hline
\end{tabular}

represents long-term infection and increases the risk of progression to gastric cancer, it is important to determine if the existence of IM makes infection eradication more difficult. Even though there are multiple treatment regimens, the standard triple therapy is still the first choice in many countries [2]. Increasing antibiotic resistance may cause the standard triple therapy to look inadequate, especially in patients with IM. Thus, we aimed to find the relationship between the density of IM and the standard triple therapy (pantoprazole $40 \mathrm{mg}$ b.i.d., amoxicillin $1 \mathrm{~g}$ b.i.d. and clarithromycin $500 \mathrm{mg}$ b.i.d.) success in $H$. pylori gastritis cases evaluated based on the Sydney classification. We also aimed to evaluate the effect of chronic inflammation, glandular atrophy, and neutrophil activity on the success of $H$. pylori eradication therapy. Our purpose is to guide clinicians in terms of treatment choice. We plan to contribute to the literature by evaluating the criteria that clinicians should consider when choosing $H$. pylori therapy.

\section{Materials and Methods}

The patients who were referred to Düzce University Hospital and Avrasya Hospital Gastroenterohepatology clinics with dyspepsia between January 2014 and December 2016 were enrolled in this retrospective study. ICD codes recorded in the hospital records were used for scanning. The medical records of the patients with diagnosis of dyspepsia and gastritis were investigated, and the ones diagnosed with $H$. pylori gastritis according to the Sydney classification system were selected. Exclusion criteria were: age $<18$ years old, history of gastric and intestinal surgery, current pregnancy or breast-feeding, history of drug allergies, history of PPI, $\mathrm{H}_{2}$ receptor antagonist, bismuth and antibiotic use in the last 4 weeks, and severe psychiatric and neurological disorders that can cause noncompliance.
The following information was obtained from patient files and pathology reports: age and sex of the patient, the site of endoscopic gastric biopsy and histopathological evaluations. Esophagogastroduodenoscopy was performed after $8 \mathrm{~h}$ of fasting. Two biopsy specimens were taken from the antrum and corpus of the stomach for pathological evaluation. Sections of paraffin blocks of biopsy materials were stained with Giemsa stain, and routine histopathological evaluations were made by light microscopy. The parameters of the Sydney classification system used for pathological diagnosis are shown in Table 1.

All patients with $H$. pylori-positive gastritis were treated with pantoprazole $40 \mathrm{mg}$ b.i.d., amoxicillin $1 \mathrm{~g}$ b.i.d., and clarithromycin $500 \mathrm{mg}$ b.i.d. for 14 days. Fifteen days after the treatment ended, 90 patients underwent esophagogastroduodenoscopy, and control biopsies were taken from the antrum and the corpus. The cases whose histopathological evaluation concluded as $H$. pylori negative were accepted as successful eradication. The other 91 patients' eradication success was evaluated with immunochromatographic test. Monoclonal antibodies were used to detect $H$. pylori antigen in stool. Absence of fecal antigen was accepted as successful eradication.

\section{Statistical Analyses}

The Statistical Package for Social Sciences (SPSS) program was used for statistical analysis. After the data of the patients were entered into the SPSS (version 18) program, continuous variables were expressed as mean \pm SD and categorical variables as percentage. The relationship between categorical features was evaluated with Pearson's $\chi^{2}$ analysis. A 95\% CI was used during all analyses performed in the SPSS program. $p<0.05$ was considered as statistically significant in all tests.

\section{Results}

One hundred and eighty-one patients were included in the study. The mean age of the patients was $55.5 \pm 7.8$, and $52 \%$ were female. The relationship between chronic inflammation, neutrophil activity, glandular atrophy, sever- 
Table 2. Comparison of the severity of chronic inflammation with $H$. pylori density and success of $H$. pylori eradication therapy

\begin{tabular}{|c|c|c|c|c|}
\hline & \multicolumn{3}{|c|}{ Chronic inflammation $^{\mathrm{a}}(n=181)$} & \multirow[t]{2}{*}{$p$ value } \\
\hline & $\begin{array}{l}\text { mild } \\
(n=16)\end{array}$ & $\begin{array}{l}\text { moderate } \\
(n=113)\end{array}$ & $\begin{array}{l}\text { severe } \\
(n=52)\end{array}$ & \\
\hline \multicolumn{5}{|l|}{ H. pylori ${ }^{\mathrm{b}}, n(\%)$} \\
\hline Mild & $10(62.5)$ & $55(48.7)$ & $11(21.2)$ & 0.002 \\
\hline Moderate & $2(12.5)$ & $40(35.4)$ & $24(46.2)$ & \\
\hline Severe & $4(25.0)$ & $18(15.9)$ & $17(32.7)$ & \\
\hline \multicolumn{5}{|l|}{ Treatment $^{\mathrm{c}}, n(\%)$} \\
\hline Unsuccessful & $2(12.5)$ & $17(15.0)$ & $22(42.3)$ & 0.001 \\
\hline Successful & $14(87.5)$ & $96(85.0)$ & $30(57.7)$ & \\
\hline
\end{tabular}

Data are presented as $n(\%) .{ }^{a}$ Shows the intensity of lymphocytes and plasma cells in lamina propria according to the Sydney system. ${ }^{\mathrm{b}}$ Refers to the density of $H$. pylori in gastric mucosa. c Shows the success of $H$. pylori eradication therapy.
Table 3. Comparison of $H$. pylori density and $H$. pylori eradication therapy success with the degree of neutrophil infiltration activity severity

\begin{tabular}{lcllll}
\hline & \multicolumn{1}{c}{ Activity $^{\mathrm{a}}(n=181)$} & \multirow{2}{*}{$p$ value } \\
\cline { 2 - 5 } & $\begin{array}{l}\text { none } \\
(n=62)\end{array}$ & $\begin{array}{l}\text { mild } \\
(n=62)\end{array}$ & $\begin{array}{l}\text { moderate } \\
(n=50)\end{array}$ & $\begin{array}{l}\text { severe } \\
(n=14)\end{array}$ & \\
\hline $\begin{array}{c}\text { H. pylori }{ }^{\mathrm{b}}, n(\%) \\
\text { Mild }\end{array}$ & $40(72.7)$ & $30(48.4)$ & $4(8.0)$ & $2(14.3)$ & 0.001 \\
$\quad \begin{array}{l}\text { Moderate } \\
\text { Severe }\end{array}$ & $10(18.2)$ & $22(35.5)$ & $27(54.0)$ & $7(50.0)$ & \\
$\begin{array}{c}\text { Treatment }, n(\%) \\
\quad \text { Unsuccessful }\end{array}$ & $5(9.1)$ & $10(16.1)$ & $19(38.0)$ & $5(35.7)$ & \\
$\quad$ Successful & $50(90.9)$ & $14(22.6)$ & $16(32.0)$ & $6(42.9)$ & 0.009 \\
\hline
\end{tabular}

Data are presented as $n(\%) .{ }^{\text {a }}$ Indicates the degree of neutrophil infiltration to lamina propria or surface epithelium according to the Sydney system. ${ }^{\mathrm{b}}$ Refers to the density of $H$. pylori in gastric mucosa. ${ }^{\mathrm{c}}$ Shows the success of H. pylori eradication therapy.
Table 4. Comparison of $H$. pylori density and $H$. pylori eradication treatment success with the severity of corpus and antrum atrophy

\begin{tabular}{|c|c|c|c|c|c|}
\hline & \multicolumn{4}{|c|}{$\operatorname{Atrophy}^{\mathrm{a}}(n=181)$} & \multirow[t]{2}{*}{$p$ value } \\
\hline & $\begin{array}{l}\text { none } \\
(n=83)\end{array}$ & $\begin{array}{l}\text { mild } \\
(n=14)\end{array}$ & $\begin{array}{l}\text { moderate } \\
(n=57)\end{array}$ & $\begin{array}{l}\text { severe } \\
(n=27)\end{array}$ & \\
\hline \multicolumn{6}{|l|}{ H. pylori ${ }^{\mathrm{b}}, n(\%)$} \\
\hline Mild & $29(34.9)$ & $2(14.3)$ & $30(52.6)$ & $15(55.6)$ & \multirow[t]{3}{*}{0.041} \\
\hline Moderate & $33(39.8)$ & $8(57.1)$ & $15(26.3)$ & $10(37.0)$ & \\
\hline Severe & $21(25.3)$ & $4(28.6)$ & $12(21.1)$ & $2(7.4)$ & \\
\hline \multicolumn{6}{|l|}{ Treatment $^{\mathrm{c}}, n(\%)$} \\
\hline Unsuccessful & $21(25.3)$ & $5(35.7)$ & $11(19.3)$ & $4(14.8)$ & \multirow[t]{2}{*}{0.390} \\
\hline Successful & $62(74.7)$ & $9(64.3)$ & $46(80.7)$ & $23(85.2)$ & \\
\hline
\end{tabular}

Data are presented as $n(\%) .{ }^{\text {a }}$ Indicates the degree of loss in the antrum and corpus glands according to the Sydney system. ${ }^{\mathrm{b}}$ Refers to the density of H. pylori in gastric mucosa. ${ }^{c}$ Shows the success of $H$. pylori eradication therapy. ity of IM, $H$. pylori density, and the success of $H$. pylori eradication therapy were evaluated. The relationship between chronic inflammation and $H$. pylori is shown in Table 2. As the severity of $H$. pylori increased, an increase in the severity of chronic inflammation $(p=0.002)$ was observed. In patients with severe chronic inflammation, the success rate of $H$. pylori eradication therapy was found to be low ( $p=0.001$; $p$ values are used as a trend in all tables).

As the severity of $H$. pylori increased, the severity of neutrophil infiltration activity also increased $(p=0.001$; Table 3). Treatment success rate was found to be significantly higher in patients without neutrophil infiltration activity $(p=0.009)$. It was similar among the patients with mild, moderate, and severe neutrophil infiltration activity $(p=0.420)$. In our study, a decrease in H. pylori density was observed as the severity of atrophy in the antrum and corpus increased $(p=0.041)$. However, there was no relationship between atrophy severity and $H$. pylori eradication success rate ( $p=0.390$; Table 4$)$.

In terms of IM severity, there was no correlation between the severity of IM and $H$. pylori eradication success $(p=0.812)$. Nevertheless, as the severity of IM increased, a decrease in the density of $H$. pylori was revealed $(p=$ 0.019; Table 5).

\section{Discussion}

H. pylori requires eradication therapy in patients with peptic ulcer, dyspepsia, gastric MALT lymphoma, atrophic gastritis, iron deficiency anemia, chronic idiopathic thrombocytopenic purpura, vitamin $\mathrm{B}_{12}$ deficiency, his- 
Table 5. Comparison of the H. pylori density and $H$. pylori eradication treatment success with the severity of intestinal metaplasia

\begin{tabular}{|c|c|c|c|c|c|}
\hline & \multicolumn{4}{|c|}{ Intestinal metaplasia ${ }^{\mathrm{a}}(n=181)$} & \multirow[t]{2}{*}{$p$ value } \\
\hline & $\begin{array}{l}\text { none } \\
(n=78)\end{array}$ & $\begin{array}{l}\text { mild } \\
(n=15)\end{array}$ & $\begin{array}{l}\text { moderate } \\
(n=59)\end{array}$ & $\begin{array}{l}\text { severe } \\
(n=29)\end{array}$ & \\
\hline \multicolumn{6}{|l|}{ H. pylori ${ }^{\mathrm{b}}, n(\%)$} \\
\hline Mild & $22(28.2)$ & $7(46.7)$ & $32(54.2)$ & $15(51.7)$ & \multirow[t]{3}{*}{0.019} \\
\hline Moderate & $32(41.0)$ & $7(46.7)$ & $16(27.1)$ & $11(37.9)$ & \\
\hline Severe & $24(30.8)$ & $1(6.7)$ & $11(18.6)$ & $3(10.3)$ & \\
\hline \multicolumn{6}{|l|}{ Treatment $^{\mathrm{c}}, n(\%)$} \\
\hline Unsuccessful & $20(25.6)$ & $3(20.0)$ & $13(22.0)$ & $5(17.2)$ & \multirow[t]{2}{*}{0.812} \\
\hline Successful & $58(74.4)$ & $12(80.0)$ & $46(78.0)$ & $24(82.8)$ & \\
\hline
\end{tabular}

Data are presented as $n(\%) .{ }^{a}$ Expresses the presence of IM in mucosa epithelium according to the Sydney system. ${ }^{\mathrm{b}}$ Refers to the density of $H$. pylori in gastric mucosa. ${ }^{\mathrm{c}}$ Shows the success of $H$. pylori eradication therapy. tory of early gastric cancer resection, and first-degree relatives who have gastric cancer [3]. The Sydney system used in the classification of chronic gastritis provides information about $H$. pylori density, activity, chronic inflammation, atrophy, and IM. As the risk of developing gastric cancer in individuals infected with $H$. pylori is proportional to the severity of inflammation and atrophy, the Sydney classification is of clinical importance as well as pathological [4]. Herein, we aimed to see whether the severity of Sydney criteria, especially IM, was effective in the success of first-line $H$. pylori eradication therapy.

The density of $H$. pylori was found to be significantly higher in patients with severe chronic inflammation $(p=$ 0.002 ). Eradication therapy success was decreased in the presence of high bacterial density $(p=0.001)$. Similarly, there was a significant decrease in the severity of $H$. $p y$ lori in patients without neutrophil infiltration, while the treatment success was significantly higher $(p=0.001)$. When a person is infected with $H$. pylori, cytotoxic agents secreted from the gastric mucosa start the inflammatory response [5]. Chronic inflammation, as $H$. pylori severity increases, leads to an increase in neutrophil activity. In conclusion, there is a positive correlation between $H$. $p y$ lori density, chronic inflammation, and neutrophil activity. The success of $H$. pylori eradication therapy is closely related to bacterial density. In patients with increased bacterial density, the success of the standard triple eradication therapy is expected to be low. In a study done by Jakic-Razumovic et al. [6] comparing the Sydney criteria before and after eradication therapy, the success of treatment was found to be lower in patients with severe chronic inflammation compared to cases with mild inflammation. However, in the same study, there was no significant change in neutrophil activity before and after treatment, and there was no relationship between bacterial load and neutrophil activity. In our study, increased bacterial load was found in cases with high neutrophil activity, which resulted in decrease in eradication success. The study of Suzuki et al. [7] also supports our study. The eradication success rate was $56.8 \%$ in the patient group consisting of 37 patients, whereas due to high neutrophil activity and bacterial density, H. pylori was not eradicated in 16 subjects.

When we evaluated the relationship between glandular atrophy, IM, and $H$. pylori eradication therapy success, atrophy and IM did not show a significant effect. $H$. $p y$ lori density was found to be decreased significantly in cases where atrophy and IM severity was increased $(p=0.041$ and $p=0.019$ ). Neutrophils and macrophages that cause chronic inflammation form free oxygen radicals and damage the surrounding tissue DNA [8]. When they cause DNA mutation in gastric isthmus stem cells, they either cause atrophy or IM [9]. Glandular atrophy is the loss of antrum and corpus glands. Long-term infection causes recurrent mucosal damage, which leads to the replacement of the glandular layer with fibrous tissue. The increase in its severity and prevalence of atrophy increases the risk of gastric cancer [10]. Two mechanisms have been proposed as the cause of decreased severity of $H$. pylori in areas with atrophy. First, $H$. pylori may be colonized only in the gastric epithelium [11]. Therefore, it cannot live on an atrophic or a metaplasic ground. Second, the bacteria can survive in a narrow $\mathrm{pH}$ range but cannot in the hypochlorhydric gastric environment [5]. In many studies, the effects of $H$. pylori eradication on atrophy and IM were investigated since they are precancerous. However, there are a limited number of studies investigating the impact of atrophy and IM on eradica- 
tion therapy $[11,12]$. Kalkan et al. [11] found, in their study of 200 patients, that treatment success was lower in patients with atrophy and IM, but due to the lack of studies on this subject, they could not explain the cause. Kamada et al. [12] could not find any significant effect of the severity of glandular atrophy in the antrum on the success of $H$. pylori eradication therapy. Our study also supports Kamada et al. [12]. Although the severity of atrophy increased, there was no significant change in treatment success. The treatment success rate was $82 \%$ even in patients with moderate to severe atrophy. This result suggests that $H$. pylori density is more effective than the presence of atrophy in treatment success.

Our study showed that the increase in IM severity, similar to glandular atrophy, did not have a significant effect on the success of $H$. pylori eradication therapy. Chen et al. [13] investigated the effect of IM on the treatment of gastric ulcer caused by $\mathrm{H}$. pylori and found that the rate of healing was higher in IM-positive cases. They found that the presence of IM did not significantly affect the treatment success ( $81.6 \%$ in the IM group, $85.3 \%$ in the group without IM) and that it was not a predictor of the treatment failure. In contrast, Vázquez Romero et al. [14] compared the relationship between IM presence and the first-line therapy in their study and found the success rates to be 61.2 and $72.7 \%$ in IM-positive and -negative individuals, respectively. According to their statistically significant $(p=0.036)$ results, they suggested that the presence of IM might be a factor which decreases the success rate of the standard triple therapy. However, they emphasized that this may be due to the restrictive factors of the study, such as low number of patients and irregular follow-up. In our study, we demonstrated that the presence of IM alone had no effect on the treatment success, but it could have an effect on the density of $H$. pylori.

Due to the change in the environmental structure caused by IgA secretion and to the decreased acidity of metaplastic areas, bacteria cannot survive in these areas [15]. In general, although IM is considered as a sequela of inflammation and as part of the progressive process, some researchers believe that it may develop due to exogenous or dietary factors independent of $H$. pylori [16]. In their study, Konakci et al. [16] found that the presence of $H$. pylori was low (1.8\%) in patients with IM, and they attributed this to the fact that the detection of IM areas was limited only to the biopsy area studied by the pathologist, that is, pathologist's subjective evaluation. In another study done on 358 patients evaluating gastric mucosal changes in $H$. pylori gastritis, there was no significant relationship found between IM and bacterial density [17].
Olmez et al. [18], in their study on subtypes of gastric IM, showed that there was no significant relationship between IM and H. pylori, although they found $38.6 \%$ of $H$. pylori positivity in the complete- and the incomplete-type IM. In contrast to these studies, we found a significant relationship between the intensity of IM and H. pylori. The presence of low bacterial density in metaplastic areas enables a stable success rate even under severe metaplasia. Moreover, metaplasia subtypes are also valuable since they affect the bacterial density by providing a suitable habitat for the bacteria [19].

Another mechanism underlying the treatment success in severe IM is probably related to IM subtypes. It was reported in the Maastricht Consensus Report that the evaluation of 2 biopsies from the antrum and the corpus using the Sydney classification system showed maximum benefit in determining gastric inflammatory changes [20]. However, the Sydney classification system evaluates only the presence and intensity of IM. In a study examining gastric IM and its subtypes, IM subtyping was not found to be significant in risk assessment and it did not provide information on the prognosis [21]. In addition, in another study investigating the benefit of subtyping, the risk of progression to gastric cancer was found to be 4-11 times higher in cases with incomplete (type I) IM [19]. The necessity of initiating eradication therapy regardless of the subtypes and the need for advanced techniques in their placement results in the absence of subtyping in routine examinations. Since this is a retrospective study, the cases were examined according to the Sydney criteria, so subtyping was not done. As the studies in the literature indicate, $H$. pylori is not found in type I IM [22]. Steadman et al. [23] reported that the gastric antral biopsy results of 3 patients showed $H$. pylori in metaplastic areas. They described the presence as the transport of bacteria to metaplastic areas through the mucus and did not accept the possibility of the bacteria attaching to metaplastic areas [23]. In Genta et al. [24] study on 378 patients, only in 32 patients was $H$. pylori found closely associated with IM. They attributed this relationship to different types of IM. Based on these studies, the fact that bacteria were not found in metaplastic areas suggests that the patients included in our study were type I IM, since studies have shown that $H$. pylori can only hold on type II IM [25].

One of the most important factors determining the success of the treatment is the density of $H$. pylori in the gastric epithelium. As in our study, many studies have shown that eradication treatment success is high in cases where bacterial density is mild [26, 27]. Onal et al. [27] 
also investigated the effect of $H$. pylori density on eradication therapy and used the standard triple therapy for this purpose. In their study, they found that the treatment success rate was lower in patients who had a high density of bacteria. Although the eradication success with the standard triple therapy seems to have lost its effectiveness in the 2000s due to the increased clarithromycin resistance, it is still preferred in the first-line treatment because of its ease of use and reliability [20]. In our study, due to patients' compliance to treatment, we used the standard triple therapy and achieved a high treatment success rate $(77 \%)$. We have shown that the most valuable Sydney criterion for predicting failure in the treatment is an increase in the severity of chronic inflammation and neutrophil activity associated with an increase in the density of $H$. pylori.

One of the limitations of our study is its retrospective design, which is the reason why eradication tests are performed 2 weeks after the completion of $H$. pylori therapy. It could also have been better to perform the same tests in 181 patients to evaluate eradication success. Another limitation is the absence of subtyping. It could have given better information about the relationship between IM, pathogenesis of $H$. pylori, and eradication.

\section{Conclusion}

Since the presence of IM and atrophy is an important risk factor for progression to gastric cancer, it is important to determine if infection eradication is more difficult with IM presence. As the presence of IM suggests longterm infection, the standard triple therapy used in primary care may be inadequate in eradication. In this study, we aimed to determine the effect of these parameters on the success of the first-line treatment. We observed that the severity of chronic inflammation, where the bacterial density is the highest, was the most effective Sydney criterion for eradication success.

\section{Statement of Ethics}

This retrospective study was approved by the Ethical Review Board of Düzce University (No.: 2016/105).

\section{Disclosure Statement}

There is no conflict of interest.

\section{References}

1 Perez-Perez GI, Rothenbacher D, Brenner H. Epidemiology of Helicobacter pylori infection. Helicobacter. 2004;9(Suppl 1):1-6.

2 Ermis F, Senocak Tasci E. Current Helicobacter pylori treatment in 2014. World J Methodol. 2015 Jun;5(2):101-7.

3 Pellicano R, Ribaldone DG, Fagoonee S, Astegiano M, Saracco GM, Megraud F. A 2016 panorama of Helicobacter pylori infection: key messages for clinicians. Panminerva Med. 2016 Dec;58(4):304-17.

4 Price AB. The Sydney System: histological division. J Gastroenterol Hepatol. 1991 MayJun;6(3):209-22.

5 Clyne M, Labigne A, Drumm B. Helicobacter pylori requires an acidic environment to survive in the presence of urea. Infect Immun. 1995 May;63(5):1669-73.

6 Jakic-Razumovic J, Tentor D, Kusec V, Cuzic $\mathrm{S}$, Brkic T. Histopathological features of gastritis before and after treatment for Helicobacter pylori. Croat Med J. 2000 Jun;41(2): $159-62$.

7 Suzuki M, Mori M, Miyayama A, Iwai N, Tsunematsu N, Oonuki M, et al. Enhancement of neutrophil infiltration in the corpus after failure of Helicobacter pylori eradication. J Clin Gastroenterol. 1997;25(Suppl 1):S222-8.

8 Dixon MF, Genta RM, Yardley JH, Correa P. Classification and grading of gastritis. The updated Sydney System. International Workshop on the Histopathology of Gastritis, Houston 1994. Am J Surg Pathol. 1996 Oct; 20(10):1161-81.

9 Fenoglio-Preiser CM. Gastrointestinal Pathology: An Atlas and Text. 3rd ed. Philadelphia: Lippincott Williams \& Wilkins; 2007.

10 Correa P, Yardley JH. Grading and classification of chronic gastritis: one American response to the Sydney system. Gastroenterology. 1992 Jan;102(1):355-9.

11 Kalkan IH, Sapmaz F, Güliter S, Atasoy P. Severe gastritis decreases success rate of Helicobacter pylori eradication. Wien Klin Wochenschr. 2016 May;128(9-10):329-34.

12 Kamada T, Haruma K, Komoto K, Mihara M, Chen X, Yoshihara M, et al. Effect of smoking and histological gastritis severity on the rate of $\mathrm{H}$. pylori eradication with omeprazole, amoxicillin, and clarithromycin. Helicobacter. 1999 Sep;4(3):204-10.

13 Chen LW, Chang LC, Hua CC, Hsieh BJ, Chen SW, Chien RN. Analyzing the influence of gastric intestinal metaplasia on gastric ulcer healing in Helicobacter pylori-infected patients without atrophic gastritis. BMC Gastroenterol. 2017 Jan;17(1):1.

14 Vázquez Romero M, Boixeda de Miquel D, Valer López-Fando MP, Albéniz Arbizu E, González Alonso R, Bermejo San José F. In- testinal metaplasia: evolution after Helicobacter pylori eradication and influence in the success of eradicating therapy. Rev Esp Enferm Dig. 2003 Nov;95(11):781-4.

15 Morgan DR, Freedman R, Depew CE, Kraft WG. Growth of Campylobacter pylori in liquid media. J Clin Microbiol. 1987 Nov;25(11): 2123-5.

16 Konakcı N, Gülten M, İbanoğlu Ms, Yorulmaz H, Veyseloğlu L, Talat Ayyıldız K, et al. Kronik Aktif Gastritli Olgularda Helicobacter Pylori Sıklığı. Uludağ University Medical Faculty Journal. 2010;36(1):7-10.

17 Kara N, Urganci N, Kalyoncu D, Yilmaz B. The association between Helicobacter pylori gastritis and lymphoid aggregates, lymphoid follicles and intestinal metaplasia in gastric mucosa of children. J Paediatr Child Health. 2014 Aug;50(8):605-9.

18 Olmez S, Aslan M, Erten R, Sayar S, Bayram I. The prevalence of gastric intestinal metaplasia and distribution of helicobacter pylori infection, atrophy, dysplasia, and cancer in its subtypes. Gastroenterol Res Pract. 2015;2015: 434039 .

19 González CA, Sanz-Anquela JM, Gisbert JP, Correa P. Utility of subtyping intestinal metaplasia as marker of gastric cancer risk. A review of the evidence. Int J Cancer. 2013 Sep; 133(5):1023-32. 
20 Malfertheiner P, Megraud F, O’Morain CA, Atherton J, Axon AT, Bazzoli F, et al.; European Helicobacter Study Group. Management of Helicobacter pylori infection-the Maastricht IV/ Florence Consensus Report. Gut. 2012 May;61(5):646-64.

21 El-Zimaity HM, Ramchatesingh J, Saeed MA, Graham DY. Gastric intestinal metaplasia: subtypes and natural history. J Clin Pathol. 2001 Sep;54(9):679-83.

22 Ota $\mathrm{H}$, Katsuyama T, Nakajima S, El-Zimaity H, Kim JG, Graham DY, et al. Intestinal metaplasia with adherent Helicobacter pylori: a hy- brid epithelium with both gastric and intestinal features. Hum Pathol. 1998 Aug;29(8):846-50.

23 Steadman C, Teague C, Kerlin P, Nimmo G. Campylobacter pylori and gastric antral intestinal metaplasia. Gastroenterology. 1988 Jul;95(1):258-60.

24 Genta RM, Gürer IE, Graham DY, Krishnan B, Segura AM, Gutierrez O, et al. Adherence of Helicobacter pylori to areas of incomplete intestinal metaplasia in the gastric mucosa. Gastroenterology. 1996 Nov;111(5):1206-11.

25 Jang TJ, Kim JR, Kim DH. Adherence of Helicobacter pylori to areas of type II intestinal metaplasia in Korean gastric mucosa. Yonsei Med J. 1999 Aug;40(4):392-5.

26 Shah DK, Jain SS, Mohite A, Amarapurkar $\mathrm{AD}$, Contractor QQ, Rathi PM. Effect of $\mathrm{H}$. pylori density by histopathology on its complications and eradication therapy. Trop Gastroenterol. 2015 Apr-Jun;36(2):101-6.

27 Onal IK, Gokcan H, Benzer E, Bilir G, Oztas E. What is the impact of Helicobacter pylori density on the success of eradication therapy: a clinico-histopathological study. Clin Res Hepatol Gastroenterol. 2013 Dec;37(6):6426. 